\title{
Interlingual duplicating in the speech of bilingual children
}

\author{
Galina Chirsheva ${ }^{1 *}$, and Marina Houston ${ }^{2}$ \\ ${ }^{1}$ Cherepovets State University, Prospekt Lunacharskogo, 5, Cherepovets, 162600, Russian Federation \\ ${ }^{2}$ The University of Melbourne, Parkville VIC 3010, Melbourne, Australia
}

\begin{abstract}
Bilinguals of every age sometimes double units of one language with those of the other, especially in the situations where they have to interact with speakers of different languages. Bilingual communication stimulates code-switches, various in their structure and pragmatics. Among them, researchers observe the following phenomena in bilingual children's speech: a) double morphology, b) translation/interpreting equivalents combinations, and c) self-interpreting. However, the interrelation between structural and semantic/pragmatic aspects, on the one hand, and the developmental characteristics of childhood bilingualism, on the other hand, have been underresearched. The authors of the paper argue that various cases of interlingual duplicating can indicate the balance between the competences of children in their two languages at different stages of their bilingual development. The purpose of the study is to describe structural, semantic, and pragmatic aspects of interlingual duplicating combinations in the speech of two children who acquire Russian and English simultaneously, as well as to find the correlation between their duplications and the development of their bilingualism. The results of the study can be used for the description of childhood bilingualism and the evaluation of bilingual children's communicative competence in each of their languages and their interpreting abilities at various age stages.
\end{abstract}

\section{Introduction}

Bilingual communication stimulates code-switches, various in their structure and pragmatics. When bilinguals pronounce a morpheme, a word, a phrase, or a sentence first in one language and then add their equivalents in the other language, we observe interlinguistic duplicates, or doublers. The cases when bilinguals' reactions to the speech in one language contain semantically and/or pragmatically equivalent words or phrases in another language can also be viewed as interlingual duplicating. Such phenomena usually occur in situations where bilinguals have to interact with speakers of different languages, which stimulates activation of both.

Researchers have described the following kinds of interlingual doubling in bilingual speech: a) double morphology $[1,2,3,4]$, b) translation equivalents combinations, or doublers [5, 6, 7], and c) self-interpreting [8]. However, the interrelation between structural

\footnotetext{
* Corresponding author: chirsheva@mail.ru
} 
and semantic/pragmatic aspects, on the one hand, and the developmental characteristics of childhood bilingualism, on the other hand, have been underresearched.

The authors argue that various cases of interlingual duplicating can indicate the balance between the competences of children in their two languages at different stages of their bilingual development.

We will analyze morphological, lexical, and syntactic doubling from several points of view: as code-switching, as self-repair, and as interpreting. All these aspects will reveal different dimensions of this complex phenomenon of bilingual speech in their relation to the development of childhood bilingualism. Besides, the aspects mentioned above are interrelated with bilingual children's attitudes to languages, their pragmatic awareness of bilingual communication, and interlinguistic creativity [9].

\section{Theoretical Background}

Bilingual children have to regulate the use of two languages in their speech and sometimes - in the speech of their interlocutors. There are several types of language alternation, most salient being code choice, code-switching, interference (transference), and interpreting/translation. These individual contact phenomena include certain cases that combine characteristics of various mentioned types and show a specific feature that is common to all of them - interlingual duplicating. Some of such cases have been studied as separate ones: double morphology, translation equivalents, spontaneous interpreting, and self-interpreting.

Double morphology is an infrequent kind of code-switching, yet it is observed in the speech of almost all bilinguals; moreover, some borrowings also demonstrate traces of this phenomenon, e.g. shoes-bl, where plurality is expressed twice by two semantically and functionally equivalent morphemes - first in English by the ending $-s$ and then in Russian by the ending -bl. The phenomenon of double morphology has been studied by C. MyersScotton as a reflection of specific bilingual speech production. She underlines that only early system morphemes may be doubled in classic code-switching because such morphemes are activated together with content morphemes. The Embedded Language content morpheme is activated together with its early system morpheme, but the Matrix Language supplies as many of its system morphemes as it considers to be efficient to build its morphosyntactic frame [1, p. 134-135] [2, p. 91-93] [3, p. 350-351] [4, p. 343-344].

When a child has acquired some bilingual equivalents and is aware of their functional use $\mathrm{s} / \mathrm{he}$ sometimes produces them as a combination due to several reasons. Such equivalents are referred to as translation equivalents [5]. As researchers point out, children begin demonstrating the acquisition of the concept of semantic equivalency around their first birthdays [5, p. 234-236]. However, doubling them requires not only a certain amount of equivalents in the mental lexicon but also pragmatic reason for their appropriate employment in communication when young bilinguals begin using them as "doublers" in their speech [5, p. 219-222]. Later on, they combine comprehension of translation equivalents with their production, thus behaving as "young translators" [5, p. 230-234]. These are the first steps to developing spontaneous interpreting as a specific type of language interrelation in child bilingual speech.

Self-interpreting is observed as further development of lexical doubling when not only separate words but whole phrases and sentences are juxtaposed within a single utterance produced by a child [6]. Self-interpreting in children is viewed as a very important kind of ability to combine code-switching and spontaneous translation, as well as a preparatory stage for developing intentional translation [6, p. 189]. 


\section{Methodology and Data}

The purpose of the study is to describe structural, semantic, and pragmatic aspects of interlingual duplicating combinations (doublers) in the speech of two siblings (Mike and Alex) who acquire Russian and English simultaneously, as well as to find the correlation between their duplications (doublers) and the development of their bilingualism.

The data have been collected with the help of videotaping two children's Russian-andEnglish interactions with their parents and grandparents within a Russian family for seven years for the elder and five years for the younger of the siblings. The amount of doublers extracted from videotapes is 487 for both children.

All doublers were divided into four categories: double morphology, lexical doublers, syntactic doublers, and doublers in interpreting. Within each category, we separated Russian-English and English-Russian doublers according to the direction of duplicating.

The intraword doublers are analyzed as cases of double morphology within the framework of the Matrix Language Frame Model [1, 2, 3, 4] that combines psycholinguistic and structural aspects of bilingual speech production.

Lexical doublers (translation equivalents) in children's speech production are described according to their structural and semantic characteristics within various communicative situations.

The description of syntactic doublers includes the comparison of structural, semantic, and pragmatic characteristics of the first and the second parts to reveal their correspondence and equivalency.

Cases of interpreting other people's speech included full or partial translation, spontaneous or conscious ones, which can be the evidence of the children's awareness of semantic and functional equivalency of linguistic units.

The interpretation of lexical and syntactical doublers, as well as interpreting, includes details of adults' involvement in the process: children used doublers either by themselves, repeated them after adults, or were told to do that.

The analysis is accompanied by the description of intentions that the bilingual children employ. The final stage of the study involves correlation analysis to establish the interrelation between interlingual duplicates and the developmental paths of childhood bilingualism.

\section{Results and Discussion}

The quantitative results of the data are represented in the table below. Each type of doubler is divided into two groups according to the language of the first and the second components: Russian-English (Rus-Eng) or English-Russian (Eng-Rus).

Table 1. Types of doublers and the direction of duplicating in two siblings (Alex and Mike).

\begin{tabular}{|l|c|c|c|c|c|c|c|c|c|c|c|c|}
\hline & \multicolumn{4}{|c|}{ Alex } & \multicolumn{4}{c|}{ Mike } & \multicolumn{4}{c|}{ Total } \\
\hline & $\begin{array}{l}\text { Rus- } \\
\text { Eng }\end{array}$ & $\begin{array}{l}\text { Eng- } \\
\text { Rus }\end{array}$ & $\begin{array}{l}\text { Amo } \\
\text { unt }\end{array}$ & $\%$ & $\begin{array}{l}\text { Rus- } \\
\text { Eng }\end{array}$ & $\begin{array}{l}\text { Eng } \\
\text {-Rus }\end{array}$ & $\begin{array}{l}\text { Amou } \\
\text { nt }\end{array}$ & $\%$ & $\begin{array}{l}\text { Rus- } \\
\text { Eng }\end{array}$ & $\begin{array}{l}\text { Eng- } \\
\text { Rus }\end{array}$ & $\begin{array}{l}\text { Amo } \\
\text { unt }\end{array}$ & $\%$ \\
\hline $\begin{array}{l}\text { Morph } \\
\text { doublers }\end{array}$ & 3 & 1 & 4 & $\mathbf{3}$ & 0 & 0 & 0 & $\mathbf{0}$ & 3 & 1 & 4 & $\mathbf{0 . 1}$ \\
\hline $\begin{array}{l}\text { Lexical } \\
\text { doublers }\end{array}$ & 57 & 5 & 62 & $\mathbf{4 8}$ & 90 & 22 & 112 & $\mathbf{3 1}$ & 147 & 27 & 174 & $\mathbf{3 5 . 7}$ \\
\hline $\begin{array}{l}\text { Syntactic } \\
\text { doublers }\end{array}$ & 18 & 2 & 20 & $\mathbf{1 5}$ & 84 & 5 & 89 & $\mathbf{2 5}$ & 102 & 7 & 109 & $\mathbf{2 2 . 3}$ \\
\hline Interpreti & 5 & 39 & 44 & $\mathbf{3 4}$ & 14 & 142 & 156 & $\mathbf{4 4}$ & 19 & 181 & 200 & $\mathbf{4 1 . 9}$ \\
\hline
\end{tabular}




\begin{tabular}{|l|c|c|c|c|c|c|c|c|c|c|c|c|}
\hline ng & & & & & & & & & & & & \\
\hline Total & 83 & 47 & 130 & $\mathbf{1 0 0}$ & 188 & 169 & 357 & $\mathbf{1 0 0}$ & 271 & 216 & 487 & $\mathbf{1 0 0}$ \\
\hline
\end{tabular}

\subsection{Morphological doublers}

Double morphology was observed quite rarely and in the speech of only one boy. Alex, the younger brother produced four unique cases at the age of four, five, and six years old.

The cases demonstrated the child's linguistic creativity. Their structures follow the double morphology hypothesis for classical code-switches: doubling employs only early system morphemes expressing plurality (1), (3), (4), and possessivity (2). However, we observe the violation of the hypothesis in the first three examples: it is not the Matrix Language that adds the second early morpheme, which is a signal of the Composite Matrix Language observed in the process of language attrition $[10,11,12]$.

Russian - English direction of doubling is represented in the examples 1, 2, and 3.

1. Alex (4) $)^{\dagger}$ : “Это миньоны -s." [These are minions-s]

2. Alex (5): “Granny, look, this one - Mick-ur's." [Granny, look, this one-Micks's]

3. Alex (6): “Давай играть в шахматы-s! !” [Let's play chess-es-es]

Only one case of English - Russian double morphology (4) was observed in Alex's speech, and it is in full accordance with the double morphology hypothesis for classical code-switches: the first early system morpheme belongs to the same language - the Embedded one, while the second one is supplied by the Matrix Language that builds the morphosyntactic frame of the utterance.

4. Father suggested: "Let's play checkers." Alex (4): “A где другие checkers-bl?" [And where are other checkers-s].

There is too little evidence on how double morphology is employed, so it is too early to make generalizations about them. Some observations on the two children's bilingual behavior can suggest that Alex is more sensitive to his interlocutors' languages and eager to alternate languages to meet his parents' and grandparents' expectations. Besides, he liked to demonstrate his achievements in both languages, which can also serve as a partial explanation of double morphology. However, we should underline that such phenomena are extremely rare - only $0,1 \%$ of all doublers.

\subsection{Lexical doublers}

Combinations of lexical equivalents from two languages can be viewed upon as intrasententional code-switches, self-repair, and partial self-interpreting.

Lexical doublers were extensively used by both boys (the total amount equals 174, which makes $35,7 \%$ of all doublers). The direction of doubling from Russian to English in both boys' speech was much more active than that from English to Russian: 147 vs 27 (84 $\%$ vs $16 \%$ ). This is one of the indicators that Russian lexical competence dominates in the children's bilingual development: Russian words come first and stimulate the appearance of English equivalents.

The first Russian English and English-Russian doublers were fixed at approximately the same age - when they were 25 months old:

Alex: "Собака, бака, dog" and "Dark, (тем)но",

Mike: "Баба, granny" and "Dog, ава-ва".

While Russian-English doublers have been appearing in the children's speech ever since they first used them, English-Russian ones were fixed in Alex's speech only when he was

\footnotetext{
$\dagger$ The name of the child is followed by his age - the number of years (in brackets).
} 
two years old, and Mike stopped using them at about four years old. This fact can signal the growing Russian language dominance in the children's bilingual competence.

Most doublers were nouns that denoted the things from the children's everyday life: food (salt, tea, cheese, ice-cream, banana), animals, including toy-animals and the pictures of them (cat, dog, spider), people around them (man, granny, granddad, daddy, friend), some other objects the children dealt with in their everyday life at home (clock, paper, battery, hammer, fire) and outside (house, car, truck, moon, snow). They also doubled the words Yes and No in their answers. Words of other parts of speech were doubled very rarely (dark). Mike's doublers were more numerous than those in Alex, demonstrated more semantical and structural variability since they included some verbs (open, sleep, repair), adverbs (much, more, enough, again, upstairs), and the pronoun $m y$.

The children's doubling activated at the period when their bilingual vocabulary included enough equivalents. It is also important, that they differentiated the languages and the interlocutors who spoke these languages. They were aware of the communicative situations that required using both languages. All these facts developed the children's pragmatic competence and their sensibility to the contexts where doublers could be appropriate. When they added English equivalents they self-repaired their language choice in the conversations with English-speaking adults, thus using the addressee-oriented pragmatic function. The same is true for the employment of inducing function: the children requested something more effectively from their English interlocutors. When they wanted to show off their English competence, they also added English equivalents to their Russian ones. When Mike was nine years old, he commented on those doublers that he noticed in his speech or the speech of his brother, thus employing metalinguistic pragmatic function. In those rare cases when the children doubled English words with Russian ones, they were usually checking something for themselves (Paper? Бумагy?) or introduced their Russian-speaking interlocutors into their conversation.

\subsection{Syntactic doublers and self-interpreting}

Syntactic doublers have much in common with self-correction, self-interpreting, and intersententional code-switching.

They were less numerous than lexical doublers and appeared later - around three years old in both Alex and Mike. The direction of syntactic and lexical doubling is the same: Russian-first doublers prevail and the prevalence is much more salient (99\%). This is the evidence of later and less developed syntactic equivalence in the children's bilingual competence, which demonstrates Russian dominance of their bilingualism.

Structural and semantic characteristics of English components within doublers appeared more deficient than their Russian counterparts, e.g.

Alex (3): "Я делаю дом. I building a house."

Mike (3): “Вкусное такое. It is good.” (about juice).

Alex (4): "Я спал. I sleeping."

Mike (4) : "А здесь кто живет? Who lives here?"

Mike (6) : “Давай играть. Let's play!"

Most syntactic doublers were short sentences represented in requests, questions, and statements. If Russian components were structurally complex, children doubled them in English asking adults' help, and then repeated the structures after them. 


\subsection{Interpreting}

Interpreting other people's speech is one of the most frequent kinds of interlingual doubling in both children. Most cases have been induced by adults who asked the boys to give equivalents to English or Russian terms.

Most interlingual doubling via interpreting had the direction that was reversed in comparison with the children's lexical and syntactical doubling of their speech: both of them interpreted from English into Russian in $90 \%$ of all cases. This fact shows that comprehension of English speech has always been much more active than its production.

The first cases of spontaneous interpreting from English were observed at the age of about two years old, while interpreting from Russian started half a year later and was fixed very rarely, especially in Alex.

At the earliest stages, the children translated separate words. Later, they translated either full utterances or chose in them only keywords and gave their equivalents.

Alex (2) (translated his grandmother's statement: "Granddad is sleeping." For his mother): “Деда (c)namb”. [Grandad sleep].

Alex (3) (in reply to his grandmother's statement: "Another dove", gave the Russian variant): “Один”. [One].

Alex (4) (having heard on TV: "I can help you!", the grandmother asked Alex: "Can уои translate this into Russian?", and he answered: “Да: я помогу тебе”. [Yes, I'll help you].

Alex (5) (in reply to his grandmother's statement: "These are cows."): "Коровbl". [Cows].

Mike (1) (in reply to the question: "Where is your granny?" pointed at her): "Баба".

Mike (2) (translated his mother's statement: "Папа пошел в туалет" for his grandmother): "Papa pee-pee."

Mike (2) (as a reaction to grandmother's statement: "It's a bеe"): “Это пчелка". [It's a bee].

Mike (3) (in reply to his grandfather's question: “Have you had your sleep?”): “Да, $九$ nосnал". [Yes, I have slept].

Mike (4) (when he wanted to go out, his grandmother said: "Yes, but it's raining", and he said to his mother: "Мама, знаешь, что бабушка сказала? Что там идет дождь". [Mummy, do you know what granny said? That it's raining].

Mike (5) (after grandmother's statement: "Granddad is ill” translated for his mother): "Дедушка заболел”. [Granddad is ill].

Mike (5) (helped his younger brother who asked for tea in Russian by translating his request into English): "Please, pour me some tea".

Mike (6) (in reply to his grandmother's explanation about wearing glasses: "It's because I have bad eyesight"): "Я тоже плохо вижу". [I also have bad eyesight].

Mike (7) (in reply to his father's question: "Are you behaving yourself?"): "Я xорошо веду".

Mike (8) (in reply to his grandmother's request: "Do you know the Russian for coconuts?"): “Кокось»".

The development of interpreting/translation abilities follows the main tendency of dominant bilingualism: the children understand speech addressed to them in both languages, but the translation from the non-dominant language to the dominant one remains more active and productive than in the reverse direction. This tendency has been observed in the children's conversations with English-speaking adults: having listened to English utterances they are addressed, they give appropriate Russian replies that included equivalent words, phrases, and even sentences.

The situations that stimulated interpreting were sometimes arranged by parents: one of them told the child to ask the other parent something and then return with the reply. Since 
the children in this family are brought up within the « one parent - one language » strategy, they know that father's English utterance should be translated into Russian for their mother, while mother's Russian utterance should be translated into English. Usually, the children have more problems when they interpret Russian utterances into English for their father. Another reason why they fail to do this is that they are aware of their father being Russian. Though they have always been positive about being spoken to in English, for their speech they choose the language in which they feel more confidant.

The children have never refused to translate/interpret when they are asked to, and they seem to enjoy the process.

\section{Conclusion}

The results of the study can be used for the description of balanced/unbalanced development of childhood bilingualism and bilingual speech at various age stages, as well as for the evaluation of bilingual children's communicative competence in each of their languages and their interpreting abilities.

Doubling is a very important phenomenon in the process of bilingual development because it serves as an indicator of the children's awareness of bilingual and monolingual mode, metalinguistic and metacommunicative abilities, and the ability to use self-repair and specific bilingual strategies.

Though infrequent, each case of double morphology provides various information on the development of child bilingualism: grammatical competence - the acquisition of grammemes in both languages and clear understanding of their equivalency; linguistic creativity - since such word-forms never occur in adults' speech, the children invent them all by themselves.

All cases of interlingual doubling show the children's awareness of various pragmatic aspects of the communicative situations they participate: languages of the interlocutors, the appropriateness of the language/languages they use, their attitude to the languages, the willingness to communicate and to interpret their speech and the speech of other people.

Additional information on childhood bilingual development is provided by the direction of the units doubled and their structural and semantic characteristics: 1) if the first elements belong to the "stronger" language and then they are dubbed with those from the "weaker" one, the children demonstrate their positive attitude even to the language they do not feel to be an effective means of communication; 2) if the first elements belong to the "weaker" language, the children either self-interpret the information for the monolingual speakers of the "stronger" language and thus include them to the communication, or they wish to show off by demonstrating their bilingualism and interpreting skills.

Further research aims at the analysis of structural, semantic, and pragmatic characteristics of child bilingual speech, as well as comparative studies of code-switches and other language contact phenomena in child and adult interactions, both longitudinal and cross-sectional.

\section{Acknowledgments}

This work was supported by the Russian Foundation for Basic Research, grant No. 18-01200260 .

This paper is published with financial support of Russian Foundation for Basic Research, project № 20-012-22046. 


\section{References}

1. C. Myers-Scotton, Duelling Languages: Grammatical Structure in Code-Switching (2 ${ }^{\text {nd }}$ ed.). Oxford: Clarendon Press (1997).

2. C. Myers-Scotton, Contact Linguistics: Bilingual Encounters and Grammatical Outcomes. Oxford: Oxford University Press (2002)

3. C. Myers-Scotton, J.L. Jake, Revisiting the 4-M model: Codeswitching and morpheme election at the abstract level. The International Journal of Bilingualism, 21 (3), pp. 340-366 (2017)

4. C. Myers-Scotton, J.L. Jake, A universal model of code-switching and bilingual processing and production. In B. Bullock, \& A. Toribio (eds.), The Cambridge handbook of linguistic code-switching, Cambridge, UK: Cambridge University Press (pp. 336-357) (2009)

5. A. DeHouwer, Bilingual First Language Acquisition. Bristol; Buffalo; Toronto: Multilingual Matters (2009)

6. Z. Gergely, Code-mixing in the speech of a 2;8 year-old Hungarian-English bilingual child. In Z. Lengyel, J. Navracsics, \& O. Simon (eds.), Applied Linguistic Studies in Central Europe, v. 1, Veszprem: Univ. of Veszprem (pp. 149-154) (1997)

7. G. Saunders, Bilingual children: From birth to teens. Clevedon: Multilingual Matters (1988)

8. G. Chirsheva, Self -interpreting by bilingual children. Suvremena Lingvistica, 36 (70), pp. 173-193 (2010)

9. G. Chirsheva, M. Houston, The Attitude of Russian-English Monoethnic Bilingual Children to Their Bilingualism. J. of Psycholonguistics, 2 (18), pp. 98-107 (2013)

10. A. Bolonyai, In-between languages: language shift/maintenance in childhood bilingualism. International J. of Bilingualism, 2 (1), pp. 21-43 (1998)

11. E. Schmitt, Early bilinguals - incomplete acquirers or language forgetters? In Studia Humaniora et Paedagogica Collegii Narovensis. Narva: Tartu Ulikool (pp. 311-330) (2008)

12. E. Schmitt, Overt and covert codeswitching in immigrant children from Russia. International J. of Bilingualism, 4 (1) (pp. 9-28) (2000) 